\title{
P4 MEDICINE AS A TOOL FOR STIMULATING HEALTHY LIFESTYLE AND THE BASIS OF TEACHING PREVENTION TO STUDENTS OF GENERAL MEDICINE AND PEDIATRICS
}

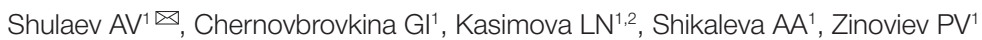

${ }^{1}$ Kazan State Medical University, Kazan, Russia

${ }^{2}$ City Clinic No. 21 of the Ministry of Health of the Republic of Tatarstan, Kazan, Russia

\begin{abstract}
This article focuses on approaches to implementing the principles of P4 medicine, specifically, stimulating prevention-based thinking among students of faculties of general medicine and pediatrics. Below, we describe a pilot approach to teaching hygiene that was implemented at the Department of General Hygiene (Kazan State Medical University). Considering the gnoseological role of empathy, we designed an interactive workbook for students taking a course in Hygiene. The workbook allows the student to engage in empathic interactions and discourse about the studied subject with the teacher and peers. After the course, the students were surveyed; their degree of engagement in the learning process and their expectations were evaluated. The respondents rated their interest in Hygiene before starting the course as 5.6 and 5.7 points on the 10-point scale (for the traditional and innovative courses, respectively). During the course, the score increased to 5.8 and 8.6 points for the traditional and innovative courses, respectively. Our pilot project demonstrates the need for reviewing the strategy of teaching hygiene and prevention-related disciplines at clinical faculties and including the principles of P4 medicine in the medical curriculum, thus allowing the student to effectively perform their professional duties in primary healthcare.
\end{abstract}

Key words: P4 Medicine principles, hygienic thinking, preventative counseling, coaching technologies, a unified preventative medicine environment in Russian Federation, professional standards, position requirements.

Author contributions: Shulaev AV — data acquisition and analysis, study concept and design, manuscript draft and editing, approval of the final version of the manuscript; Chernovbrovkina GI — data acquisition and analysis, study concept and design, manuscript draft and editing; Kasimova LN- data acquisition and analysis, study concept and design, manuscript draft and editing; Shikaleva AA- data acquisition and analysis, manuscript draft; Zinoviev PV — data acquisition and analysis, manuscript draft.

$\triangle$ Correspondence should be addressed: Alexey Shulaev

Butlerova 49, Kazan, 420012, shulaev8@gmail.com

Received: 12.04.2021 Accepted: 24.05.2021 Published online: 25.06.2021

DOI: $10.24075 /$ rbh.2021.010

\section{«4-П МЕДИЦИНА» КАК ИНСТРУМЕНТ ФОРМИРОВАНИЯ ЗДОРОВОГО ОБРАЗА ЖИЗНИ У НАСЕЛЕНИЯ И ОСНОВА ПРЕПОДАВАНИЯ ГИГИЕНЫ СТУДЕНТАМ ЛЕЧЕБНОГО И ПЕДИАТРИЧЕСКОГО ПРОФИЛЯ}

А. В. Шулаев ${ }^{1}$, Г. И. Чернобровкина ${ }^{1}$, Л. Н. Касимова ${ }^{1,2}$ А. А. Шикалева ${ }^{1}$, П. В. Зиновьев

${ }^{1}$ Казанский государственный медицинский университет, г. Казань, Россия

2 Городская поликлиника № 21 Министерства здравоохранения Республики Татарстан, г. Казань, Россия

Разработка подходов реализации принципов «4-П медицины» в формировании профилактического мышления у студентов лечебного и педиатрического факультетов при изучении дисциплины «Гигиена». Пилотный подход к преподаванию дисциплины «Гигиена», реализованный на кафедре общей гигиены Казанского государственного медицинского университета. Руководствуясь гносеологическим значением эмпатии, мы разработали интерактивную тетрадь для изучения дисциплины «Гигиена», работая по которой, студент включается в эмпатийно-дискурсивное взаимодействие с собеседником (преподаватель и/или студенты) по изучаемой тематике. По итогам использования данного подхода мы провели социологический опрос среди студентов с целью определения степени вовлеченности в процесс обучения и оценки их ожиданий. В результате исследования было установлено, что средняя оценка (по 10-ти бальной шкале) заинтересованности студентов в изучении «Гигиены» до начала обучения на кафедре составила: у обучающихся по традиционной программе - 5,6 баллов, у обучающихся по инновационной программе - 5,7 баллов. Свою заинтересованность в изучении дисциплины в процессе обучения на кафедре оценили: обучающиеся по традиционной программе - в 5,8 баллов, обучающиеся по инновационной программе - 8,6 баллов. Реализуемый пилотный проект на базе кафедры общей гигиены Казанского ГМУ наглядно показывает необходимость пересмотра преподавания дисциплины «Гигиена» на клинических факультетах с обязательным включением в учебный процесс принципов «4-П медицины», что позволит будущему врачу более эффективно выстраивать профессиональную деятельность в условиях оказания первичной медико-санитарной помощи населению.

Ключевые слова: принципы «4-П медицины», гигиеническое мышление, профилактическое консультирование, коучинг-технологии, единая профилактическая среда Российской Федерации, профессиональные стандарты, трудовые функции.

Вклад авторов: А. В. Шулаев - сбор и анализ данных, разработка концепции и дизайна исследования, написание текста рукописи, научное редактирование, окончательное одобрение рукописи; Г. И. Чернобровкина - сбор и анализ данных, разработка концепции и дизайна исследования, написание текста рукописи, научное редактирование; Л. Н. Касимова - сбор и анализ данных, разработка концепции и дизайна исследования, написание текста рукописи, научное редактирование; А. А. Шикалева - сбор и анализ данных, подготовка рукописи; П. В. Зиновьев - сбор и анализ данных, подготовка рукописи

$\bowtie$ Для корреспонденции: Алексей Владимирович Шулаев ул. Бутлерова, 49, г. Казань, 420012, shulaev8@gmail.com

Поступила: 12.04.2021 Статья принята к печати: 24.05.2021 Опубликована онлайн: 25.06.2021

DOI: 10.24075/rbh.2021.010 
P4 medicine is a modern approach to healthcare that is preventive, predictive, personalized and participatory. This healthcare model focuses on the individual, is based on the preclinical detection of the disease, prioritizes prevention and active participation of the patient in changing their lifestyle [1].

The state-funded program Healthcare Development in the Russian Federation emphasizes the importance of prevention as one of the key strategic directions to curb the spread of diseases, reduce premature mortality and morbidity [2, 3].

At the same time, approaches to creating a consolidated healthcare environment with a focus on prevention address a few critical perspectives from the patient and the healthcare provider, including:

- lack of critical thinking skills among the population, which makes it difficult to critically analyze information about lifestyles;

- varying levels of media and information literacy (MIL);

- unconscious motives that prevent the individual from leading a healthy lifestyle (unmet needs, low income, lack of knowledge or skills, personality traits);

- the imperfect quality control mechanism for openaccess medical information on the Internet;

- lack of P4 educational programs and P4 clinicians;

- unfulfilled preventive potential of the Russian healthcare system;

- lack of scientifically established reference ranges of rational lifestyles for diseased persons, including cancer patients.

These key points dictate the need for P4-oriented physicians with preventive thinking.

Federal educational standards for specialties 31.05.01 (General medicine) and 31.05 .02 (Pediatrics) provide a list of universal and general professional competencies that are based on professional standards and include consultation and motivational skills to encourage the patient to change their lifestyle.

A competency-based approach is an opportunity to introduce original teaching methods to a syllabus. Educational institutions can exercise a certain degree of freedom in designing a curriculum. Thus, they comply with federal educational standards set by the state and at the same time promote ideas of developmental teaching.

It should be noted that boundaries are somewhat blurred between education and mentoring, health improving practices and personal development, social and pedagogical influences and psychotherapy [4]. This underscores the need for clear-cut pedagogical, social and psychology-related content in medical educational curricula and requires certain pedagogical skills from clinicians

Interactive teaching helps to effectively apply theoretical knowledge and personal experience when solving diagnostic tasks $[5,6,7,8]$ and fosters clinical thinking $[9,10]$. It can be broken down in 2 components: a specific component that includes medical knowledge and skills and a non-specific (logical) component that pertains to productive thinking.

According to the literature review of interactive teaching methods commonly used in teaching hygiene/preventionrelated disciplines at the faculties of general medicine and pediatrics, the most popular methods are teaching in smal groups, discussions, case studies and multimedia presentations $[11,12,13,14,15,16]$.

Vvedensky Al writes that interactive teaching facilitates cooperative learning, allowing students to assimilate new knowledge, acquire new competencies, pay heed to the opinion of their opponent and work out a decision together
[17]. Teaching in small groups, multimedia presentations and didactic teaching methods are used to teach about sanitary inspections of educational institutions; the case study method is used to analyze factual data provided by the local branches of Rospotrebnadzor $[18,19]$.

Another widely used teaching method is a simulation game [20], which involves improvised modeling of activities commonly performed by a specific group and simulation of problems that may arise during such activities.

Cinquain poems and on-online crossword puzzles are much rarer. A team of researches [21] has proposed a few unique productive out-of-class activities based on the Pedagogical workshop for knowledge building and Critical thinking technologies that create a favorable learning atmosphere, help students to build research skills and be emotionally involved in the search for knowledge.

According to Yusupova IP [22], professional competencies of the clinician form a system of individual, professionally significant skills, qualities and knowledge united by the humane attitude to patients and colleagues and pursuit of personal and professional perfection.

The focus on building hygiene/prevention-related competencies among medical students is justified because students majoring in general medicine are quite indifferent to them. Unfortunately, traditional teaching methods often fail to engage students in out-of-class activities and independent practice [12].

Prevention is a professional challenge for GPs and pediatricians; its importance is emphasized in the standards for the medical profession. Notably, experts [4] underscore that current educational standards for the medical profession guide academic staff to actively introduce prevention in the curriculum. The student is expected to learn how to effectively educate their future patients and work out a prevention strategy tailored to the patient.

Studies of interactive teaching methods for hygiene/ prevention-related disciplines are scarce and aim at improving the efficacy of content assimilation, increasing interest in the subject, and stimulating active knowledge acquisition in the context of traditional curricula. To our knowledge, there have been no projects with a focus on interactive teaching and innovative curricula for hygiene/prevention-related disciplines taught at clinical faculties. Such innovative curricula should be based on the educational roadmap that leads the student to their final destination: acquisition of hygiene/prevention-related competencies that satisfy the demands of next-generation preventive medicine.

The aim of the study was to develop approaches to implementing the principles of P4 medicine and to stimulate preventive thinking among students enrolled in the Hygiene course at the faculties of General Medicine and Pediatrics.

\section{METHODS}

A pilot approach to teaching Hygiene implemented at the Department of General Hygiene of Kazan State Medical University was harmoniously integrated in the curriculum and met the requirements $\mathrm{A} / 04.7$ and $\mathrm{A} / 05.7$ specified in the professional standards and universal/professional competencies of federal educational standards.

The novelty of the approach lies in its factor-based interactive nature and the use of task-oriented, developmental approach.

The factor-based approach implies systematization of health factors: 
- Apart from studying environmental factors, students learn about lifestyle factors that impact human health (behavior and the associated metabolic risks);

- The course provides information about environmental and lifestyle factors, as well as about informational, electromagnetic, biological and chemical factors;

- The course offers a holistic view on the factor (e.g., noise is not only an industrial but also a communal factor; harmful effects occur when a permissible exposure limit or a maximum allowable concentration is exceeded, as well as in the absence and/or insufficient exposure to the factor, e.g. noise above the recommended exposure level may lead to neurosensory hearing loss, whereas the absence of any noise may lead to hallucinations, etc.);

- The course focuses on exposure, adaptation and combination/complex effects of the studied factors.

The problem-based approach is based on case studies; the cases are true to life and are solved using a strict preventivethinking algorithm.

The developmental approach helps students to build a positive, stable attitude to prevention, develops systemic, logical and structured thinking and motivates students to lead a healthy lifestyle and pursue professional development.

The interactive approach relies on the use of simulation games, practice in a clinical setting, lectures by clinicians, excursions, discussion, brain storms, etc.

In order to implement the interactive approach to teaching hygiene and prevention, we designed an interactive workbook, a didactic tool that structures practical classes according to the principles of cognitive and emotional learning.

This interactive workbook is a part of the Hygiene course and is intended for independent work. The workbook contains exercises on different aspects of hygiene and prevention; the exercises are grouped in sections presented in the following order: CONCEPTION, COACHING, PRACTICUM.

The key idea behind the workbook is emphatic knowledge acquisition, which facilitates value-based perception of information and effective content assimilation.

This approach proposes that empathy is a way of cognition and acceptance of values; it was based on the results of our own study of values and empathy conducted in 523 students of Kazan State Medical University between 2016 and 2019; for the study, we used interviews and structured questionnaires based on the description of characteristics of empathic potential proposed by Rogov MG and Yusupova IM (1999).

Our study harnessed psychological, statistical and immediate observation methods. The obtained data were processed and their validity was tested by calculating relative and mean values, using Student's t-test and other statistical methods. Differences were considered significant at $p \leq 0.05$. Statistical analysis was carried out in Statistica 10.0 and MS Excel 2010.

\section{RESULTS}

In the first phase of our study, we established a correlation between the respondents' values and empathy. Twentyfour of 40 values were significantly correlated with empathy ( $p<0.05$ and $p<0.01$ for 11 and 13 values, respectively). The correlations were the strongest for the following values: knowledge acquisition $\left(r_{x y}=0.48\right)$, being on good terms with people $\left(r_{x y}=0.48\right)$, honesty $\left(r_{x y}=0.37\right)$, communication with like-minded people $\left(r_{x y}=0.36\right)$, creativity $\left(r_{x y}=0.36\right)$, and high aspirations $\left(r_{x y}=0.348\right)$.
The established correlations show that the stronger the empathy, the more significant are the following values: being on good terms with people and knowledge acquisition. Perhaps, the impact of empathy on knowledge acquisition can be explained by its gnoseological aspect.

Based on the established correlations, we developed an interactive workbook, which involves the student in empathic interactions and discourse.

The sections of the workbook are presented in the order that implies gradually increasing engagement in the discipline. The first section - CONCEPTION - introduces the student to the subject of the practical class; the initial level of knowledge is tested by brain storming; then the teacher guides students to use information resources needed for solving a particular professional task. After students have systematized their knowledge of terms, concepts and principles of hygienic factor ranking, the teacher proceeds to the next section - COACHING. This section includes exercises on using the acquired knowledge/skills based on impressions and emotions coming from real life scenarios or literature sources/ films, which aids effective knowledge assimilation. The section contains tests for knowledge assimilation, which enhances the personal responsibility of students in understanding the subject. The last section - PRACTICUM — presents cases that help the student to master prevention-oriented thinking.

This approach was implemented in the innovative Hygiene course and used for 3 academic years (2016/2017, 2017/2018 and 2018/2019) at the faculties of General Medicine and Pediatrics of Kazan State Medical University. Traditionally, the Hygiene course is taught in academic years 2 and 3 . After the course, a total of 290 students were surveyed, of them 147 had taken the traditional Hygiene course and 143 had taken the innovative Hygiene course. The survey aimed to determine the level of student engagement in the learning process and to evaluate students' expectations.

Students who had taken the traditional course gave an average of 5.6 out of 10 points to their interest in Hygiene before the course; in the innovative course group the score was 5.7 points $(p>0.05)$.

During the course, the interest score increased to 5.8 points in the traditional course group and to 8.6 points in the innovative course group $(p<0.05)$. When asked to rate how well their expectations of the course had been met, the traditional course group rated it as 3.8 points on average; for the innovative course groups, the average score was 8.6 points $(p<0.01)$. The study shows that student engagement and interest in hygiene as the basis of prevention medicine are still maintained among senior students. Interest and engagement were also assessed based on the 3-year-long membership of students in the undergraduate research society at the Department of General Hygiene after completing the Hygiene course and passing the exam. Students continued to attend the society and went on with their research, integrating it with clinical disciplines taught in senior years.

The level of competencies to meet the requirements A/04.7 and A/05.7 of the federal educational standards can be evaluated as threshold, advanced and excellent, as proposed by the task force of our pilot project.

- Information literacy can be assessed using a structured interview (open-ended questions);

- Maturity of prevention-based thinking can be assessed during case studies;

- Theoretical knowledge is assessed using tests.

This approach facilitates transition from recognition and reproduction (memorizing) to understanding, persuasion, creativity, and practical application of the obtained knowledge. 


\section{CONCLUSIONS}

Current reforms of public healthcare dictate the need for change in the way prevention- related disciplines are taught at medical educational institutions. Development of new federal educational standards and their implementation in practical healthcare necessitate the search for new approaches to shaping prevention-oriented thinking among students taking a course in Hygiene at the faculties of general medicine and pediatrics.

According to the professional standards, a general practitioner and a pediatrician receive accreditation and then begin their career in primary healthcare. Here, they are faced with the problem of motivating their patient to lead a healthy lifestyle and have to develop patient-tailored recommendations on prevention.

Our pilot project implemented at the Department of Hygiene of Kazan State Medical University demonstrates the need for reviewing the strategy of teaching hygiene and prevention-related disciplines at clinical faculties and including the principles of P4 medicine in the medical curriculum, thus allowing the student to effectively perform their professional duties and promote prevention in primary healthcare.

\section{References}

1. Hood L, Flores MA personal view on systems medicine and the emergence of proactive P4 medicine: predictive, preventive, personalized and participatory. N Biotechnol. 2012; 29 (6): 613624. doi: 10.1016/j.nbt.2012.03.004

2. The state program for the development of public health services of the Russian Federation, approved by the Decree of the Government of the Russian Federation of December 24, 2012 No. 2511-r.

3. The concept of long-term socio-economic development of the Russian Federation for the period until 2020, approved by the Order of the Government of the Russian Federation of November 17, 2008 N 1662-r.

4. Kopysheva EN, Mishina IE, Baklushina EK. Razvitie kompetencij profilakticheskoj dejatel'nosti budushhego vracha v obrazovatel'noj srede vuza. Vestnik Ivanovskoj medicinskoj akademii. 2011; 16 (3): 62-65.

5. Shhelchkova NN, Tjumaseva ZI, Orehova IL. Ispol'zovanie interaktivnyh form obuchenija studentov pri izuchenii kursa «Vozrastnaja anatomija fiziologija i gigiena». Vestnik Cheljabinskogo gosudarstvennogo pedagogicheskogo universiteta. 2015; 6: 125-134

6. Plaksina I.V. Interaktivnye tehnologii $\vee$ obuchenii i vospitanil Vladimir: Izd-vo «VIGU»; 2014; 163 s.

7. Pogorelova IG. Optimizacija prepodavanija gigieny dete i podrostkov na sovremennom jetape. Sistema menedzhmenta kachestva: opyt i perspektivy. 2016; 5: 39-42.

8. Tjumaseva ZI, Orehova IL. Zdorov'esberegajushhie interaktivnye tehnologii kak sistemoobrazujushhij faktor prirodosoobraznogo obrazovatel'nogo processa. Vestnik Shadrinskogo gosudarstvennogo pedagogicheskogo instituta. 2014; 4 (24): 27-31.

9. Ogol'cova EG, Hmel'nickaja OM. Formirovanie aktivnogo obuchenija kak sredstvo razvitija poznavatel'noj dejatel'nosti studentov. V sbornike: Regional'naja nauchno-prakticheskaja internet-konferencija Razvitie kachestva vysshego professional'nogo obrazovanija v sovremennyh uslovijah 2009; 29-133 s.

10. Panina T.S., Vavilova L.N. Sovremennye sposoby aktivizacii obuchenija. M.: Akademija; 2008. 176 s.

11. Sudilovskaja NN. Primenenie tehnologii kejs-metoda v prepodavanil predmeta «Osnovy pediatrii i gigieny». Mezhdunarodnyj zhurnal jeksperimental'nogo obrazovanija. 2015; 2: 403-404.

\section{Литература}

1. Hood L, Flores MA personal view on systems medicine and the emergence of proactive P4 medicine: predictive, preventive, personalized and participatory. N Biotechnol. 2012; 29 (6): 613624. DOI: 10.1016/j.nbt.2012.03.004.

2. Государственная программа развития здравоохранения Российской Федерации, утвержденная Распоряжением Правительства РФ от 24 декабря 2012 года № 2511-р.

3. Концепция долгосрочного социально-экономического развития Российской Федерации на период до 2020 года утвержденная Распоряжение Правительства РФ от 17 ноября 2008 № 1662-p.

12. Perevalov AJa, Anambaeva Al. Nekotorye itogi rossijskokazahstanskogo sotrudnichestva v sfere vysshego medicinskogo obrazovanija. Mir obrazovanija — obrazovanie v mire. 2009; 1 : 117-121.

13. Nefedov PV, Kolycheva SS, Korneenkov AD. Ob optimizacii prepodavanija gigieny. Mezhdunarodnyj zhurnal jeksperimental'nogo obrazovanija. 2014; 4: 183-185.

14. Valeeva MA. Ispol'zovanie interaktivnyh metodov obuchenija studentov v obrazovatel'noj srede vuza. Filosofija obrazovanija. 2010; 2 (31): 75-82.

15. Gushhin Ju V. Interaktivnye metody obuchenija v vysshej shkole. Psihologicheskij zhurnal Mezhdunarodnogo universiteta prirody, obshhestva i cheloveka «Dubna». 2012; (2): 1-18.

16. Sergeeva ND, Danilova TK, Shkavro LR, Kolesnikova IJu. Interaktivnye metody obuchenija v medicinskom vuze. Sistema menedzhmenta kachestva: opyt i perspektivy. 2016; 5: 44-47.

17. Vvedenskij Al. Interaktivnye metody obuchenija studentovmedikov i metody autentichnoj samoocenki dlja korrektirovanija individual'noj obrazovatel'noj traektorii. V sbornike: Psihologopedagogicheskie problemy obrazovanija $v$ medicinskom vuze sbornik nauchnyh trudov pod redakciej N.G. Samojlova; Rjazan'. 2016; 31-35.

18. Klimov VP. Versii i principy dizajn-obrazovanija. $V$ sbornike: Materialy Vserossijskoj konferencii Funkcionirovanie kolledzha kak edinogo uchebno-nauchno-proizvodstvennogo kompleksa; M.: OO० «AvtoPrint». 2010; 76-77.

19. Tkachenko EV, Shtejnberg VJe. Didakticheskij dizajn instrumental'nyj podhod. Obrazovanie i nauka. Izvestija UrO RAO. 2006; 1 (37): 58-65

20. Artjuhina Al. Pedagogicheskoe proektirovanie obrazovatel'noj sredy kafedry pri situacionno-sredovom podhode. Vestnik VolGMU. 2006; 4 (16): 24-26.

21. Atadzhanova ASh. Primenenie sistemy interaktivnyh metodov obuchenija kak rezul'tat formirovanija obshhih kompetencij studentov-medikov. Nauka i mir. 2016; 3 (31): 25-27.

22. Jusupov IR, Gizetdinova LR. Professional'nye kompetencii budushhego vracha. Innovacionnoe razvitie sovremennoj nauki. V sbornike: Sbornik statej Mezhdunarodnoj nauchno-prakticheskoj konferencii; Ufa. RIC BashGU 2014; 22-26.

4. Копышева Е.Н., Мишина И.Е., Баклушина Е.К. Развитие компетенций профилактической деятельности будущего врача в образовательной среде вуза. Вестник Ивановской медицинской академии. 2011; 16 (3): 62-65.

5. Щелчкова Н.Н., Тюмасева З.И., Орехова И.Л. Использование интерактивных форм обучения студентов при изучении курса «Возрастная анатомия, физиология и гигиена». Вестник Челябинского государственного педагогического университета. 2015; 6: 125-134.

6. Плаксина И.В. Интерактивные технологии в обучении и воспитании Владимир: Изд-во «ВлГУ»; 2014; 163 с. 
7. Погорелова И.Г. Оптимизация преподавания гигиень детей и подростков на современном этапе. Система менеджмента качества: опыт и перспективы. 2016; 5: $39-42$.

8. Тюмасева З.И., Орехова И.Л. Здоровьесберегающие интерактивные технологии как системообразующий фактор природосообразного образовательного процесса. Вестник Шадринского государственного педагогического института. 2014; 4 (24): 27-31.

9. Огольцова, Е. Г., Хмельницкая О.М. Формирование активного обучения как средство развития познавательной деятельности студентов. В сборнике: Региональная научнопрактическая интернет-конференция Развитие качества высшего профессионального образования в современных условиях 2009; 29-133 с.

10. Панина Т.С., Вавилова Л.Н. Современные способь активизации обучения. М.: Академия; 2008. 176 с.

11. Судиловская Н.Н. Применение технологии кейс-метода в преподавании предмета «Основы педиатрии и гигиены». Международный журнал экспериментального образования. 2015; 2: 403-404.

12. Перевалов А.Я., Анамбаева А.И. Некоторые итоги российско-казахстанского сотрудничества в сфере высшего медицинского образования. Мир образования образование в мире. 2009; 1: 117-121.

13. Нефедов П.В., Колычева С.С., Корнеенков А.Д. Об оптимизации преподавания гигиены. Международный журнал экспериментального образования. 2014; 4: 183-185.

14. Валеева М.А. Использование интерактивных методов обучения студентов в образовательной среде вуза. Философия образования. 2010; 2 (31): 75-82.
15. Гущин Ю.В. Интерактивные методы обучения в высшей школе. Психологический журнал Международного университета природы, общества и человека «Дубна». 2012; 2: 1-18

16. Сергеева Н.Д., Т.К. Данилова, Л.Р. Шкавро, Колесникова И.Ю. Интерактивные методы обучения в медицинском вузе. Система менеджмента качества: опыт и перспективы. 2016; 5: 44-47.

17. Введенский А.И. Интерактивные методы обучения студентов-медиков и методы аутентичной самооценки для корректирования индивидуальной образовательной траектории. В сборнике: Психолого-педагогические проблемы образования в медицинском вузе сборник научных трудов под редакцией Н.Г. Самойлова; Рязань. 2016; 31-35.

18. Климов В.П. Версии и принципы дизайн-образования. В сборнике: Материалы Всероссийской конференции Функционирование колледжа как единого учебно-научно-производственного комплекса; М.: ООО «АвтоПринт». 2010; 76-77.

19. Ткаченко Е.В., Штейнберг В.Э. Дидактический дизайн инструментальный подход. Образование и наука. Известия УрО РАО. 2006; 1 (37): 58-65.

20. Артюхина А.И. Педагогическое проектирование образовательной среды кафедры при ситуационно-средовом подходе. Вестник ВолГМУ. 2006; 4 (16): 24-26.

21. Атаджанова А.Ш. Применение системы интерактивных методов обучения как результат формирования общих компетенций студентов-медиков. Наука и мир. 2016; 3 (31): 25-27.

22. Юсупов И.Р., Гизетдинова Л.Р. Профессиональные компетенции будущего врача. Инновационное развитие современной науки. В сборнике: Сборник статей Международной научно-практической конференции; Уфа. РИЦ БашГУ 2014; 22-26. 